\title{
SPECIFIC CELLULAR AND HUMORAL IMMUNE RESPONSES INDUCED BY DIFFERENT ANTIGEN PREPARATIONS OF ECHINOCOCCUS MULTILOCULARIS METACESTODES IN PATIENTS WITH ALVEOLAR ECHINOCOCCOSIS
}

\author{
NICOD L.*, BRESSON-HADNI S.*, VUITTON D.A.*, EMERY I.*, GOTTSTEIN B.**, AUER H.*** and LENYS D..*
}

\section{Summary :}

A specific proliferation of the peripheral blood mononuclear cells (PBMC) stimulated by antigens of Echinococcus sp. has been shown in patients with cystic as well as alveolar echinococcosis. However, the development of a major granulomatous reaction around the parasitic larvae is a characteristic feature of the local immune response to $E$. multilocularis while humoral immune responses seem to predominate in E. granulosus infection. The aim of this study was to analyse the specific proliferation of the PBMC from 36 patients with alveolar echinococcosis, and 23 controls, induced by a crude preparation of $E$. multilocularis (EmcAg) as well as by two $E$. multilocularis specific antigen preparations, the Em2 antigen and the protoscolex (ESAg) antigen. The significant correlation observed between the proliferation index either by Em2 and ES or by Emc suggests that both antigens account for an important part of the lymphocyte proliferative response. The strong effect of these species specific antigens on lymphocyte proliferation is confirmed by the comparison of the results obtained in this study to those obtained in a previous study of specific cellular immunity to $E$. granulosus antigens in patients with cystic echinococcosis. The proliferation indices were significantly elevated in all those 7 patients with a proven AE who were sero-negative using the Emc ELISA, as well as in the 12 patients also seronegative, but using the Em2 ELISA. In 5 seronegative patients who had had a complete resection of the parasitic lesions two years before the lymphocyte proliferation evaluation, the PI was above the threshold value for two dilutions of EmcAg. Pl under the threshold values were obtained only in patients with residual lesions. These results suggest that $E$. multilocularis specific antigens promote the proliferation of lymphocytes which could be $\mathrm{TH}$ l cells, responsible for the intense periparasitic granulomatous reaction characteristic of alveolar echinococcosis

KEY WORDS : Echinococcus multilocularis. Alveolar echinococcosis. Lymphocyte proliferation. Em2 antigen. Protoscolex antigen

MOTS CLES : Echinococcus multilocularis, échinococcose alvéolaire. prolifé ration lymphocytaire. antigène Em2. antigène de protoscolex.
Résumé : PROLIFÉRATION LYMPHOCYTAIRE INDUITE PAR DES ANTIGĖNES SPÉCIFIQUES DANS L'ÉCHINOCOCCOSE ALVÉOLAIRE HUMAINE

Aussi bien dans l'échinococcose hydatique que dans l'échinococcose alvéolaire, il est possible d'obtenir une prolifération spécifique des lymphocytes sanguins après stimulation par les antigènes d'Echinococcus. Cependant le développement d'une réaction granulomateuse majeure autour des larves parasitaires est un des aspects caractéristiques de la réponse immune locale à $\mathrm{E}$. muttilocularis, alors que les réponses immunes humorales semblent prédominer dans l'infection par E. granulosus. Le but de cette étude était d'analyser la prolifération spécifique des lymphocytes circulants de 36 malades atteints d'échinococcose alvéolaire et de 23 sujets témoins, après stimulation par une préparation antigénique brute $d^{\prime} E$. multilocularis (EmcAg) ainsi que par deux préparations antigéniques spécifiques purifiées, l'antigène Em2 et l'antigène de protoscolex (ESAg). La corrélation significative observée entre les index de prolifération après stimulation par les trois préparations antigéniques montre que les antigènes spécifiques participent de façon importante à l'initiation de la réponse proliférative lymphocytaire. Cet effet puissant des antigènes spécifiques d'espèce est confirmé par la comparaison des résultats obtenus dans ce travail à ceux obtenus dans une étude précédemment publiée de l'immunité cellulaire spécifique vis-à-vis des antigènes $d^{\prime} \mathrm{E}$. granulosus, chez des malades atteints d'échinococcose hydatique. Les index de prolifération étaient significativement élevés chez les 7 malades, atteints d'échinococcose alvéolaire confirmée histologiquement, qui étaient séronégatifs en utilisant l'ELISA Emc, de même que chez les 12 malades, également séronégatifs mais en utilisant I'ELISA Em2. Chez 5 malades séronégatifs qui avaient eu une résection complète des lésions parasitaires 2 ans avant l'évaluation de la prolifération lymphocytaire, les index de prolifération étaient au-dessus du seuil de positivité pour les 2 dilutions d'EmcAg. Les index de prolifération en-dessous du seuil n'ont été obtenus que chez des malades qui avaient des lésions résiduelles. Ces résultats suggèrent que les antigènes spécifiques $d^{\prime} \mathrm{E}$. multilocularis sont de puissants inducteurs de prolifération lymphocytaire qui pourraient contribuer à induire l'intense réaction granulomateuse locale caractéristique de l'échinococcose alvéolaire.

\footnotetext{
* Research Unit on Health and Rural Environment (SERF), Research Group on Alveolar Echinococcosis (AREA), University of FrancheComté, F 25030 Besançon, France.

** Laboratory of Parasitology, Medicine and Veterinary Faculties of the University of Bern, $\mathrm{CH}-300 /$ Bern, Switzerland.

${ }_{* * *}$ Laboratory of Parasitology, Clinical Institute of Hygiene of the University of Vienna, A-1095 Wien, Austria.

Address for correspondence : Prof. D.A. VUITTON, Service de Médecine Interne, CHU Jean Minjoz, F 25030 BESANCON (France) Telephone: 81669733 - Fax : 81669711.
} 


\begin{tabular}{|c|c|c|c|c|c|c|}
\hline $\begin{array}{l}\text { PATIENT } \\
n^{\circ}\end{array}$ & $\begin{array}{c}\text { AGE } \\
\text { (years) }\end{array}$ & SEX & $\begin{array}{c}\text { MEDICAL } \\
\text { TREATMENT } \\
{ }_{*}^{*}\end{array}$ & $\begin{array}{l}\text { SURGICAL } \\
\text { OPERATION }\end{array}$ & $\begin{array}{c}\text { VOLUME OF } \\
\text { THE PARASITIC } \\
\text { LESION } \\
{ }_{* *}\end{array}$ & $\begin{array}{c}\text { TIME BETWEEN } \\
\text { SURGERY AND PI } \\
\text { DETERMINATION } \\
\text { (months) }\end{array}$ \\
\hline 1 & 64 & $\mathrm{~F}$ & MZ & PH & 2 & 72 \\
\hline 2 & 90 & $\mathrm{~F}$ & $\mathrm{MZ}$ & $\mathrm{PS}^{\circ}$ & 4 & - \\
\hline 3 & 69 & $\mathrm{M}$ & MZ & $\mathrm{PH}$ & 3 & 48 \\
\hline 4 & 62 & $\mathrm{M}$ & $\mathrm{MZ}$ & $\mathrm{PH}$ & 2 & 67 \\
\hline 5 & 39 & $\mathrm{M}$ & $\mathrm{MZ}$ & RH & 0 & 60 \\
\hline 6 & 67 & F & MZ & $\mathrm{PH}$ & 1 & 15 \\
\hline 7 & 68 & $\mathrm{M}$ & $\mathrm{MZ}$ & PS & 3 & 18 \\
\hline 8 & 49 & M & MZ & $\mathrm{PS}^{\circ}$ & 1 & - \\
\hline 9 & 61 & $\mathrm{M}$ & MZ & $\mathrm{RH}$ & 0 & 18 \\
\hline 10 & 68 & $\mathrm{~F}$ & $\mathrm{MZ}$ & $\mathrm{PH}$ & 2 & 108 \\
\hline 11 & 75 & $\mathrm{~F}$ & $\mathrm{MZ}$ & PS & 4 & 132 \\
\hline 12 & 62 & $\mathrm{~F}$ & $\mathrm{MZ}$ & $\mathrm{PS}^{\circ}$ & 4 & - \\
\hline 13 & 60 & $\mathrm{M}$ & $\mathrm{MZ}$ & PH & 1 & 33 \\
\hline 14 & 49 & M & $\mathrm{MZ}$ & $\mathrm{PH}$ & 1 & 72 \\
\hline 15 & 64 & $\mathrm{M}$ & $\mathrm{MZ}$ & $\mathrm{PS}^{\circ}$ & 3 & - \\
\hline 16 & 68 & F & $\mathrm{MZ}$ & PH & 2 & 24 \\
\hline 17 & 61 & $\mathrm{~F}$ & $\mathrm{MZ}$ & $\mathrm{PH}$ & 2 & 24 \\
\hline 18 & 44 & $\mathrm{M}$ & MZ & $\mathrm{PH}$ & 2 & 48 \\
\hline 19 & 72 & $\mathrm{M}$ & $\mathrm{MZ}$ & PH & 1 & 12 \\
\hline 20 & 60 & $\mathrm{M}$ & $\mathrm{MZ}$ & $\mathrm{RH}$ & 0 & 36 \\
\hline 21 & 72 & M & $\mathrm{MZ}$ & PS $^{\circ}$ & 4 & - \\
\hline 22 & 62 & $\mathrm{M}$ & $\mathrm{MZ}$ & PH & 1 & 24 \\
\hline 23 & 74 & M & $\mathrm{MZ}$ & PH & 2 & 64 \\
\hline 24 & 57 & F & $\mathrm{MZ}$ & RH & 0 & 26 \\
\hline 25 & 47 & $\mathrm{~F}$ & $\mathrm{MZ}$ & $\mathrm{PH}$ & 2 & 66 \\
\hline 26 & 41 & $\mathrm{~F}$ & $\mathrm{O}$ & $\mathrm{RH}$ & 0 & 40 \\
\hline 27 & 65 & M & MZ & PS $^{\circ}$ & 0 & - \\
\hline 28 & 65 & F & $\mathrm{O}$ & PH & 0 & 120 \\
\hline 29 & 42 & M & $\mathrm{MZ}$ & $\mathrm{RH}$ & 0 & 60 \\
\hline 30 & 53 & M & MZ & PH & 3 & 72 \\
\hline 31 & 42 & $\mathrm{~F}$ & $\mathrm{O}$ & $\mathrm{RH}$ & 0 & 21 \\
\hline 32 & 47 & M & $\mathrm{MZ}$ & $\mathrm{RH}$ & 0 & 56 \\
\hline 33 & 70 & M & $\mathrm{MZ}$ & $\mathrm{RH}$ & 0 & 25 \\
\hline 34 & 74 & M & MZ & PH & 4 & 47 \\
\hline 35 & 80 & M & $\mathrm{MZ}$ & $\mathrm{PH}$ & 1 & 46 \\
\hline 36 & 77 & F & $\mathrm{O}$ & PS & 4 & 48 \\
\hline
\end{tabular}

Table I. - Clinical and parasitological features of 36 patients with alveolar echinococcosis

$\mathrm{PS}^{\circ}$ : no surgery; RH : radical hepatectomy; PH : palliative hepatectomy; PS : palliative surgery without hepatic resection.

${ }^{*} \mathrm{MZ}$ : Mebendazole (4,5 g/day).

** : semi-quantative evaluation :

$1<15 \%$ of the hepatic volume

$2<15 \%,<30 \%$

$3>30 \%,>50 \%$

$4>50 \%$ and/or metastasis. 


\section{INTRODUCTION}

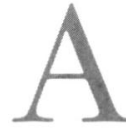

very long period of time elapsed before the cestodes Echinococcus granulosus and E.

multilocularis gained the status of two different species (Vogel 1955): in fact these two cestodes have many morphological similarities and share more than $80 \%$ of their antigenic determinants (Kagan et al., 1960; Capron et al., 1970). However, the diseases which are the consequences of the larval development of both species in animals and in humans are quite different : Cystic echinococcosis (CE), caused by the development of E. granulosus larvae, looks like a benign tumor and is associated with a very mild infiltration by immune response cells (Miguet $e t$ al., 1991); Alveolar echinococcosis (AE), caused by the development of E. multilocularis larvae, is similar to a malignant tumor (Miguet et al., 1991; Miguet and Bresson-Hadni, 1989). Larvae of the latter species have unlimited growth, despite a very strong granulomatous reaction which has been shown to play a major role both in the defence of the host against the parasite (Vuitton et al., 1989; Bresson-Hadni et al., 1990) and in the occurrence of the complications of the disease (Bresson-Hadni et al., 1988).

A specific proliferation of the peripheral blood mononuclear cells (PBMC) stimulated by antigen preparations of Echinococcus sp. has been shown in patients with CE (Siracusano et al., 1988) and AE (BressonHadni et al., 1989; Gottstein et al., 1991). In patients with $\mathrm{AE}$, the specific $\mathrm{T}$-cell proliferation appears to be greater than in those with $\mathrm{CE}$, and lasts more than 4 years after complete removal of the parasitic tissue (Bresson-Hadni et al., 1989). In patients receiving a large amount of immunosuppressive drugs after a liver transplantation for $\mathrm{AE}$, significant proliferation indices have been shown to be associated with the persistance of parasitic larvae in other organs; in some cases they even reach levels higher than those observed before transplantation (Bresson-Hadni et al., 1991). The antigens which are specific to each species could be responsible for stimulation of the host immune response which could differ quantitatively and/or qualitatively. Such specific antigen preparations have been proposed as diagnostic tools for the measurement of specific antibodies (Gottstein et al., 1983; Auer et al., 1989). However, their respective ability to induce T-cell proliferation has not been previously compared. The aim of this study was to analyse the specific proliferation of the PBMC from patients with AE. The study utilized a crude preparation of E. multilocularis (EmcAg) as well as two E.multilocularis specific antigenic preparations, the Em2 antigen (Em2Ag) (Gottstein et al., 1983) and the protoscolex derived antigen (ESAg) (Auer et al., 1989). Results were correlated with the parasitic mass, and with the levels of specific antibodies measured using EmcAg and Em2Ag

\section{MATERIALS AND METHODS}

\section{PATIENTS :}

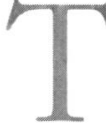

hirty-six patients (mean age : 60.5 years) with a histologically proven $\mathrm{AE}$, and originating from Franche-Comté $(n=33)$, Haute-Savoie $(n=1)$ and Lorraine $(n=2)$, France, were included in this study. The clinical features of these patients are given in Table I. Among these patients, 10 had had a radical resection of the liver parasitic lesions, and 32 patients were receiving mebendazole at the time of the study. No patients of this series had an abortive form of $\mathrm{AE}$, or had had a liver transplantation before the lymphocyte proliferation study. The PBMC were also tested in 23 control subjects ( 6 men, 17 women, mean age : 34.5 , range $24-52$ ). All these healthy subjects were seronegative for AE using Emc- and Em2ELISA and lived in Franche-Comté, France.

\section{ECHINOCOCCUS ANTIGENS :}

E. multilocularis crude antigen (EmcAg) was prepared from parasitic peritoneal lesions maintained in Meriones unguiculatus, as described previously (Bresson-Hadni et al., 1989). A solution of $25 \mathrm{mg}$ of the lyophilized extract in $10 \mathrm{ml}$ of TRIS ACM buffer was used for the proliferation assays. The total amount of protein determined by the Bio-Rad protein assay was $1,420 \mu \mathrm{g} / \mathrm{ml}$.

Em2 antigen (Em2Ag) was obtained from parasitic peritoneal lesions in Meriones unguiculatus by affinity chromatography using a rabbit anti-hydatid fluid IgG coupled to $\mathrm{CNBr}$-Sepharose $4 \mathrm{~B}$, as previously described (Gottstein et al., 1983). Using this procedure, the column retained the common antigens shared by E. multilocularis and E. granulosus, whilst the Em2 specific antigen passed through the column. The total protein amount was $704 \mu \mathrm{g} / \mathrm{ml}$.

E. multilocularis ES antigen (ESAg) was prepared from the supernatant of cultures of the protoscoleces of E. multilocularis as described previously (Auer et al., 1989). The supernatants were removed after 3, 5, $7,9,11$ and 13 days of culture and frozen $\left(-20^{\circ} \mathrm{C}\right)$ until required. Pooled supernatants were concentrated tenfold with polyethylene glycol 20,000, dialysed against PBS at $+4^{\circ}$ for $48 \mathrm{~h}$, and finally precipitated by trichloroacetic acid. The total protein amount was $92 \mu \mathrm{g} / \mathrm{ml}$. 


\section{PROLIFERATION ASSAY :}

Peripheral Iymphocytes were separated from heparinized blood $(20 \mathrm{ml})$ by conventional centrifugation on a Ficoll-Hypaque gradient. Isolated cells were washed twice, and re-suspended at $5 \times 10^{5}$ cells $/ \mathrm{ml}$ in RPMI 1640 medium (Eurobio) supplemented with 10 $\%$ heat-inactivated human $\mathrm{AB}$ serum, $25 \mathrm{mM}$ glutamine, $100 \mathrm{U} / \mathrm{ml}$ penicillin, $100 \mu \mathrm{g} / \mathrm{ml}$ streptomycine. Triplicate cultures were prepared in curvebottomed microwell culture plates (Nunc, Roskilde, Denmark), at $5 \times 10^{4}$ cells/well by addition of $100 \mu \mathrm{l}$ RPMI medium. Then $20 \mu \mathrm{l}$ of sterile antigens (EmcAg, Em2Ag or ESAg) were added at various concentrations. In all experiments, cultures with optimal doses of phytohaemagglutinin (PHA : $20 \mu \mathrm{I}$ ) and cultures without antigen were also set up as controls.

After 3 days of culture at $37^{\circ} \mathrm{C}$ in a humidified atmosphere containing $5 \% \mathrm{CO}_{2}$, the proliferative response was assessed by the addition of $20 \mu \mathrm{l}$ containing 1 $\mu \mathrm{Ci} 3 \mathrm{H}$-methylthymidine (specific activity $1 \mathrm{mCi} /$ $\mathrm{mmol}$ ) to each well. After $18 \mathrm{hr}$ at $37^{\circ} \mathrm{C}$, cells were harvested on glass fibre filters (Nunc, Roskilde, Denmark) and prepared for $\beta$-spectrometry by adding $3 \mathrm{ml}$ Dynagel (Baker, Holland). Net counts per minute $(\mathrm{cpm})$ of triplicate cultures were measured, and the proliferative response was expressed as a "proliferation index" (PI) calculated as follows :

$$
\text { PI }=\frac{\text { cpm in stimulated culture }}{\text { cpm in control unstimulated culture }}
$$

PI was considered as significant for any value $>3$ with PHA, EmcAg,Em2Ag and ESAg (1:5), and $>2$ with EmcAg, Em2Ag and ESAg (1:50, 1:500) as described previously (Bresson-Hadni et al., 1989).

Determination of the optimal concentration of the three antigen preparation EmcAg, Em $2 A g$ and ESAg

The T-lymphocyte proliferation of PBMC from five patients with AE was studied with ten concentrations of each antigenic preparation (EmcAg, Em2Ag and ESAg); the mean PI obtained are shown in Fig. 1.

A low level of reactivity was obtained at the highest concentrations (undiluted and dilutions 1:2 and 1:3) of the three antigenic preparations. A higher degree of reactivity was observed for intermediate dilutions from $1: 5$ to $1: 500$ of the 3 antigenic preparations. It was followed by a dose-dependent decrease of the lymphocyte proliferation. A 1:5 dilution of each antigen was chosen as the highest antigenic concentration used in this study; however the 1:50 and 1:500 dilutions were also tested.

\section{SEROLOGICAL ASSAYS :}

Evaluation of the specific IgG humoral immune response against E. multilocularis was carried out using a) the Em2-ELISA as described by Gottstein et al (Gottstein et al., 1983) and b) an Emc- ELISA developed in our laboratory, according to the method described for Em2-ELISA and using a crude preparation of E. multilocularis as antigen. The results were considered positive for any value $>0 \%$ for Emc and Em2.

\section{STATISTICAL TESTS :}

Non-parametric statistical comparison test (MannWhitney U-test) and Spearman's correlation test were used to test differences between patients and control subjects and correlation between the PI and levels of specific antibodies or volume of the parasitic lesions, respectively.

\section{RESULTS}

ANTIBODY RESPONSE ASSESSED BY EMC- AND EM2ELISA :

Specific anti-E.multilocularis antibodies, assessed by ELISA, were present in 30 (/36) and 23 (/36) sera tested against Emc and $\mathrm{Em} 2$ respectively. Individual results of antibody levels are shown in Table II.

\section{LYMPHOCYTE PROLIFERATION WITH PHA}

After stimulation with PHA, the cpm measured in the Iymphocyte cultures from patients ranged from 13,346 to 62,221 (vs 32,117 to 82,946 in control subjects, and 183 to 1,411 without any stimulation).

The mean PI obtained with the PBMC of the 36 patients (145.0) was significantly lower than that observed in the control group $(224.0)(\mathrm{p}=0.007)$ (Fig. 2).

\section{LYMPHOCYTE PROLIFERATION WITH EMCAG}

Results of the lymphocyte proliferation assays with EmcAg are shown in Fig. 2. At the 1:5 dilution of EmcAg, the cpm measured in the lymphocyte cultures from patients ranged from 132 to 3,600. The differences between the PI values obtained from the patients and those obtained from the control subjects were highly significant for the three concentrations of EmcAg $(p<0.001)$.

At the 1:5 dilution, the $\mathrm{Pl}$ was higher than 3 in 32 (/36) patients with AE and in 7 control subjects

At the 1:50 dilution, it was higher than 2 in 32 


\begin{tabular}{|c|c|c|}
\hline $\begin{array}{l}\text { PATIENT } \\
n^{\circ}\end{array}$ & $\begin{array}{c}\text { Emc- ELISA }(\%) \\
\text { positive }:>0\end{array}$ & $\begin{array}{c}\text { Em2- ELISA }(\%) \\
\text { positive }:>0\end{array}$ \\
\hline 1 & 70 & 37 \\
\hline 2 & 80 & 29 \\
\hline 3 & 42 & 3 \\
\hline 4 & 32 & 1 \\
\hline 5 & 4 & 1 \\
\hline 6 & 9 & 0 \\
\hline 7 & 91 & 61 \\
\hline 8 & 49 & 43 \\
\hline 9 & 0 & 0 \\
\hline 10 & 41 & 44 \\
\hline 11 & 5 & 1 \\
\hline 12 & 84 & 60 \\
\hline 13 & 75 & 51 \\
\hline 14 & 57 & 31 \\
\hline 15 & 0 & 0 \\
\hline 16 & 25 & 1 \\
\hline 17 & 32 & 8 \\
\hline 18 & 68 & 81 \\
\hline 19 & 64 & 20 \\
\hline 20 & 12 & 3 \\
\hline 21 & 10 & 0 \\
\hline 22 & 19 & 2 \\
\hline 23 & 33 & 1 \\
\hline 24 & 0 & 0 \\
\hline 25 & 24 & 0 \\
\hline 26 & 21 & 5 \\
\hline 27 & 9 & 0 \\
\hline 28 & 0 & 0 \\
\hline 29 & 37 & 34 \\
\hline 30 & 2 & 0 \\
\hline 31 & 0 & 0 \\
\hline 32 & 36 & 23 \\
\hline 33 & 1 & 0 \\
\hline 34 & 8 & 0 \\
\hline 35 & 0 & 0 \\
\hline 36 & 57 & 51 \\
\hline
\end{tabular}

Table II. - Specific antibody responses assessed by ELISA using different antigenic preparations of E. multilocularis : crude extract, Emc; purified specific extract, Em2. Results are expressed as percent of the standard serum.

patients and in 10 control subjects. A significant dose effect relationship was observed in the group of patients.

The PI was significantly elevated in all those 6 patients with a proven $\mathrm{AE}$ who were seronegative using the Emc- ELISA, as well as in the 13 patients also seronegative but using the Em2- ELISA.

In the seronegative patients $n^{\circ} 9,24,28,31$ and 33 who had had a complete resection of the parasitic lesions 2 years before the Iymphocyte proliferation evaluation, the PI was above the threshold value for $1 / 5$ and $1 / 50$ dilutions of EmcAg. In all the patients with a complete resection of the parasitic lesions, the PI obtained at the 1:5 or 1:50 dilutions of Emc antigenic preparation were above 3.8 and 2.7 respectively. Although there was no significant difference between the PI values obtained in the group of patients with radical resection and that of patients with residual lesions, it should be noted that $\mathrm{Pl}$ under the threshold values were only obtained from patients with residual lesions.

\section{LYMPHOCYTE PROLIFERATION WITH EM2AG}

Results of Iymphocyte proliferation assays with Em2Ag are shown in Fig. 3. At the 1:5 dilution of Em2Ag, the cpm measured in the Iymphocyte cultures from patients ranged from 400 to 1,066 . The PI calculated from the patients' $\mathrm{PBMC}$ were significantly higher than those obtained from the control PBMC at the 1:50 dilution. However, the difference was no longer significant at the 1:500 dilution. At the 1:5 dilution, 
the PI was higher than 3 in $16(/ 32)$ patients and 4 healthy controls. At the 1:50 dilution, the PI was above the threshold value in 17 patients and in 1 control.

\section{LYMPHOCYTE PROLIFERATION WITH ESAG}

Results of Iymphocyte proliferation assays with ESAg are shown in Fig. 3. At the 1:5 dilution of ESAg, the $\mathrm{cpm}$ measured in the Iymphocyte cultures from patients ranged from 138 to 3,243. The PI calculated from the patients with PBMC were significantly higher than those obtained from the control subjects' PBMC at the 1:5 and 1:50 dilutions. However, the difference was no longer significant at the 1:500 dilution. At the 1:5 dilution, the PI was higher than 3 in $15(/ 21)$ patients and 3 healthy controls. At the 1:50 dilution, the PI was above the threshold value in 16 patients and in 2 uninfected controls.

\section{CORRELATIONS BETWEEN THE PROLIFERATION}

INDICES OBTAINED WITH THE DIFFERENT ANTIGENIC PREPARATIONS

Spearman's correlation analysis showed significant correlations between the PI obtained with EmcAg and those obtained with ESAg at the 1:5 dilution $(r=0.60$, $\mathrm{p}<0.003)$, and at the 1:50 dilution $(\mathrm{r}=0.44, \mathrm{p}<$ 0.04) (Fig. $4 \mathrm{~A}$ and B). However, at the highest dilution of these two antigenic preparations (1:500) there was no significant correlation. Conversely, there were significant correlations between the PI values obtained using EmcAg and Em2Ag $(r=0.56, p<0.0008)$ (Fig. 4C), and with Em2 and ES $(r=0.48, p<0.05)$, at the 1:500 dilution (Fig. 4D) but there was no correlation at lower dilutions (1:5 and 1:50).

\section{CorRelations BETWEen IMMUNOLOGICAL AND ClI-} NICAL PARAMETERS

- PI and antibody levels: There were no significant positive or negative correlations between specific antibody levels assessed by Emc-, and Em2-ELISA and lymphocyte responses. The PI values obtained with crude and specific antigens were high, even in seronegative patients (especially in $n^{\circ} 9,15,24$, and 28).

- PI and clinical features: There was no correlation between the PI values and the volume of the parasitic lesions at the time of the study or with any aspect of the patients' past-history (age, sex, medical treatment, interval between surgery and the lymphoproliferative tests).

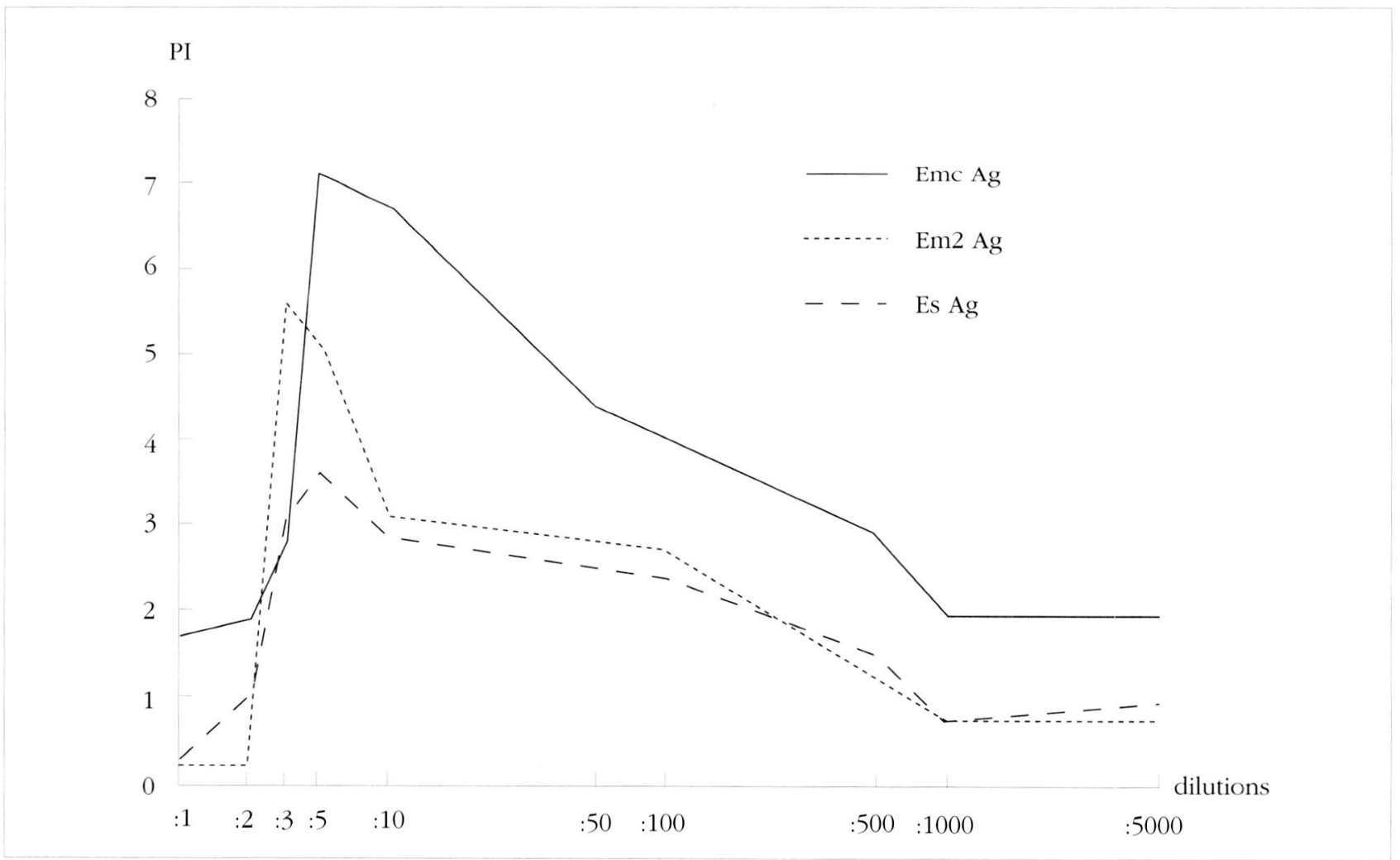

Fig. 1. - Means of the proliferation indices (PI) obtained from PBMC stimulated with three different antigenic preparations of $E$. $m u l t i l o c u$ laris, EmcAg, Em2Ag and ESAg at ten dilutions in five patients with alveolar echinococcosis. The protein concentrations of the antigenic preparations were respectively $1,420 \mu \mathrm{g} / \mathrm{ml}, 704 \mu \mathrm{g} / \mathrm{ml}$ and $92 \mu \mathrm{g} / \mathrm{ml}$ for Emc, Em2 and ES antigens. 

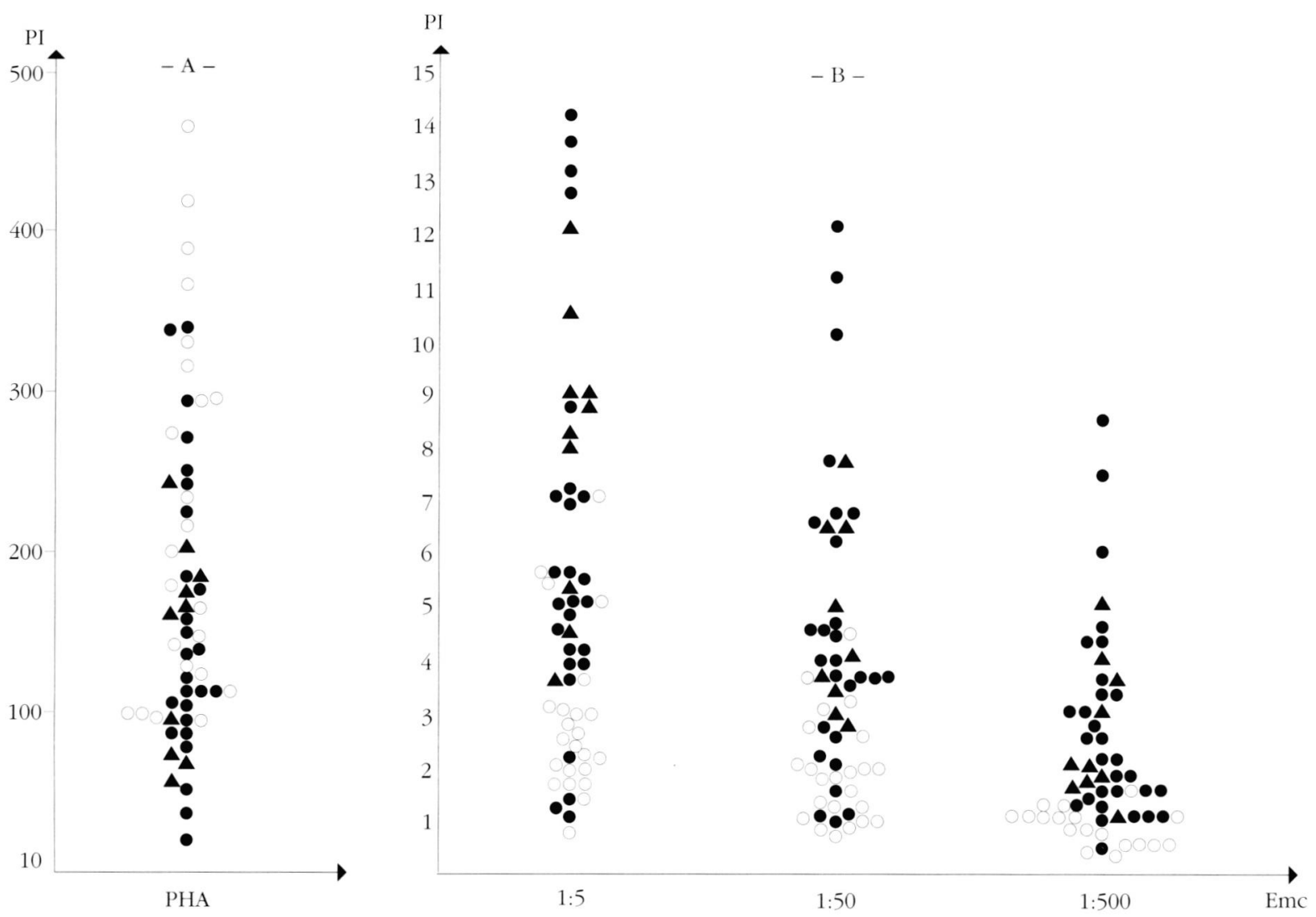

Fig. 2. - Proliferation index (Pl) of PBMC from healthy controls $\left(^{\circ}\right)$ and patients with alveolar echinococcosis with $(\boldsymbol{\nabla})$ and without $(\bullet)$ radical hepatectomy, (A) stimulated with phytohaemagglutinin (PHA) and (B) crude extract of E. multilocularis, Emc at the 1:5, 1:50 and 1:500 dilutions. The protein content of the $1: 5$ dilution of the Emc antigenic preparation was $284.0 \mu \mathrm{g} / \mathrm{ml}$.
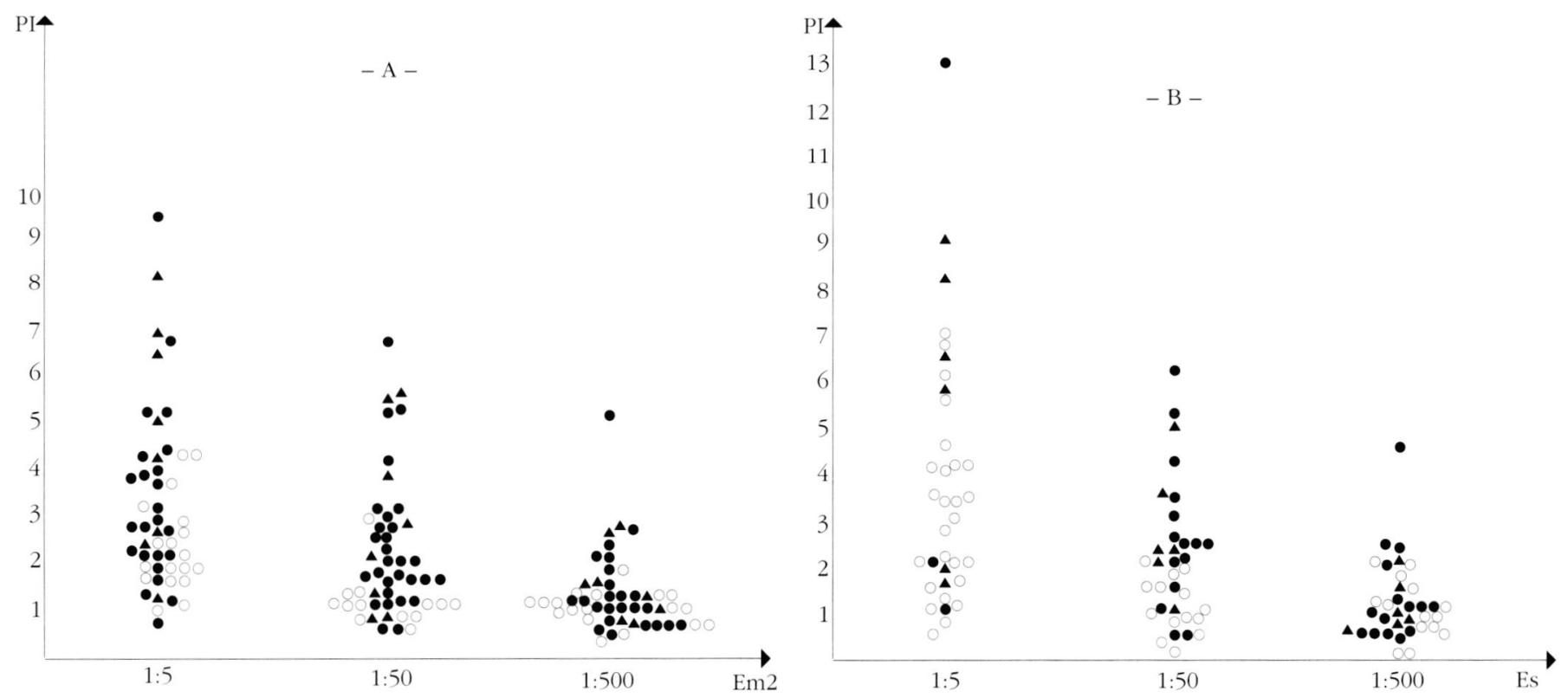

Fig. 3 - Proliferation index (Pl) of PBMC from healthy controls $\left(^{\circ}\right)$ and patients with alveolar echinococcosis with $(\boldsymbol{\Delta})$ and without radical hepatectomy $(\bullet)$ stimulated by a purified specific extract Em2Ag (A) and the protoscolex supernatant ESAg (B) of E. multilocularis. The protein content of the 1:5 dilution of Em2Ag and ESAg antigenic preparations were $140.8 \mu \mathrm{g} / \mathrm{ml}$ and $18.4 \mu \mathrm{g} / \mathrm{ml}$ respectively. 

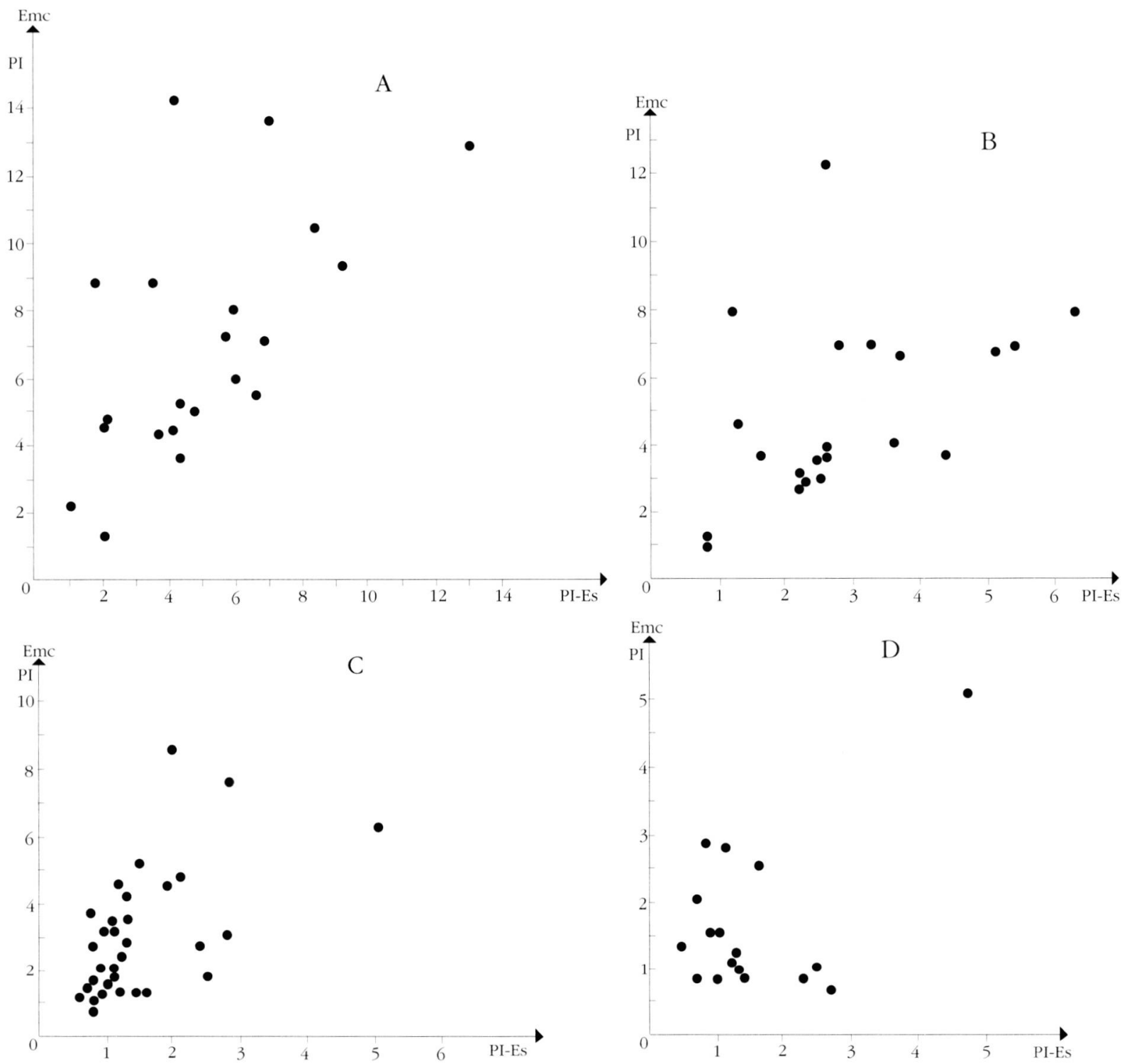

Fig. 4 - Relationship between the proliferation indices (PI) of the PBMC obtained using the different antigenic preparations of $E$. multilocularis antigens in patients with alveolar echinococcosis : EmcAg versus ESAg, at the 1:5 dilution $(r=0.60, p<0.003)(A)$ and at the $1: 50$ dilution $(r=0.44, p<0.04)(B)$; EmcAg versus Em2Ag at the $1: 500$ dilution $(r=0.56, p<0.0008)(\mathrm{C})$ and Em2Ag versus ESAg at the $1: 500$ dilution $(\mathrm{r}=0.48, \mathrm{p}<0.05)(\mathrm{D})$.

\section{DISCUSSION}

T he results of our present study confirmed the existence of a reactivity of PBMC to Em Ag in patients with AE. Moreover, it indicates that the proliferation induced by a crude antigenic preparation is partly related to species-specific antigens, namely Em2 and ES. The significant PI occasionally obtained from controls' PBMC could be explained by an intrinsic mitogenic potency of E. multilocularis Ag, as suggested by previous studies with $\mathrm{Ag}$ from various cestodes (Judson et al., 1987). However, it can be noted that significant PI were only observed in some control subjects, all of them having lived in endemic areas for many years, so that a previous contact with E. multilocularis could not be excluded.

Compared to the response obtained with Emc, with regard to the protein concentration, it appears that these antigens induced a stronger response than Emc which contained other antigenic proteins shared by E. multilocularis and E. gramulosus. In fact, the antigenic protein concentrations used in the cell cultures at the $1: 5$ dilution for Em2Ag, ESAg and EmcAg were $12.82 \mu \mathrm{g} / \mathrm{ml}, 1.68 \mu \mathrm{g} / \mathrm{ml}$ and $25.82 \mu \mathrm{g} / \mathrm{ml}$ respectively. The strong effect of these species-specific antigens on Iymphocyte proliferation is confirmed by the compa- 
rison of the results obtained in this study to those obtained in a previous study of specific cellular immunity to E. granulosus antigen in patients with CE (Siracusano et al., 1988). In that study, a specific proliferation of the PBMC stimulated by antigen preparation of E. granulosus was demonstrated (Siracusano et $a l ., 1988)$. However, the antigenic protein concentrations $(200 \mu \mathrm{g} / \mathrm{ml})$ required to obtain a similar degree of proliferation as that observed in our study was 15 and 100 fold higher than those of Em2 and ES antigens respectively. Thus, the ability to induce a specific lymphocyte proliferation is definitely greater using E. multilocularis specific antigens. This could explain the development of the periparasitic granulomatous reaction which characterizes $\mathrm{AE}$ lesions compared to those of CE. Cloning of the $\mathrm{T}$ cell subpopulations induced in this reaction, which is now under investigation, will give interesting information on their functional properties, especially their cytokine synthesis and secretion capacities. The occurrence of granulomatous reactions in parasitic diseases, for instance in murine schistosomiasis which, like $\mathrm{AE}$, is characterized by a granulomatous liver disease, has been shown to be related to CD4+ T cells (Chikunguwo et al., 1991). Murine CD $4+$ T helper cells have recently been subdivided into two groups according to their Iymphokine secretion profile. It would be of major interest to isolate CD4+ TH1 Iymphocytes specific to E. multilocularis antigens (Em2Ag or ESAg) from the granulomatous reaction of human AE. This may allow us to study their ability to mediate DTH reaction and to produce cytokines as it has been previously done for schistosomiasis (Chikumguwo et al., 1991).

In a recent study, using a crude protein extract, Gottstein et al., (1991) found an inverse relationship between the intensity of the specific cell-mediated immunity and the evolution of the disease. In fact, the lowest lymphoproliferative response occurred among inoperable cases, whereas the status of cured $\mathrm{AE}$ patients was always characterized by a high in vitro lymphoproliferative response. Our results seem to indicate a similar relationship using EmcAg although the statistical correlation was not significant. However, it was not observed using Em2Ag and ESAg.

ESAg is a $62 \mathrm{kDa}$ polypeptide presumably originating from an antigen released by the protoscolices into the culture medium (excretory/secretory antigen) in a period of high activity and metabolism (Auer et al., 1989). In our study, fertile lesions containing viable protoscolices were observed in only two patients ( $n^{\circ} 13$ and $n^{\circ}$ 31) (Liance et al., 1990). Interestingly, the PI (respectively 7 and 9.2) obtained with ESAg at the $1: 5$ dilution from these patients were among the highest observed in the patient group. The observation of a positive specific cellular immune response using this antigen also in the patients without fertile lesions suggest that this antigen is expressed on another part of the metacestode.

Em2Ag is a component of the parasite, located predominantly in its laminated layer, which persists, independently of the viability status of the metacestode. The observation of a significant lymphoproliferative response to $\mathrm{Em} 2 \mathrm{Ag}$ in $\mathrm{AE}$ patients having received mebendazole for many years at the time of PI determination is therefore not suprising. Recent investigations (Gottstein, unpublished) demonstrated the dominant carbohydrate nature of the $\mathrm{Em} 2$ antigen. It may thus become interesting to focus on the subsets of lymphocytes involved in the proliferative response: such an antigen could theoretically also stimulate directly B lymphocytes.

In conclusion, these results confirm that antigens specific to E. multilocularis which are not shared by $E$. granulosus could be responsible for the major cellular immune response observed in AE. The significant correlation observed between the PI induced either by Em2Ag and ESAg or by EmcAg suggests that both antigens account for an important part of the proliferative response and, thus, for the development of TH1 clones. In fact, AE is also characterized by an important and sustained humoral immune response and it can by hypothesized that antigens shared by the two species could preferentially induce the development of TH2 clones. Howewer, a specific role of Em2Ag in B cell stimulation cannot be excluded. Alternatively, similar to that shown in schistosomiasis, the development of clones which secrete both types of cytokines (Chikunguwo et al., 1991 ) can be hypothesized. Preliminary results of spleen cell proliferation induced by EmcAg in E. multilocularis infected mice favor this hypothesis (Emery et al., unpublished data). E. multilocularis infection thus appears as another very exciting model to study the way of differentiation of T-helper clones in reference to the nature of the antigens and/or their mode of presentation to the T-helper cells.

\section{ACKNOWLEDGMENTS}

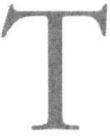
he authors thank Ms C. Benay and A. Regnier for their excellent technical assistance, Prof. H. Aspock and Dr F. Gaulard for their contributions to the study, and Ms P. Jouffroy, M. Letoublon, and L. Rose for their help in the preparation of the manuscript. 


\section{REFERENCES}

Auer H., Hermentin K. and Aspock H. : Demonstration of a specific Echinococcus multilocularis antigen in the supernatant of in vitro maintained protoscolices. Zentralblatt für Bakteriologie, Mikrobiologie und Hygiene, 1989, 268, 416-423.

Bresson-Hadni S., Lenys D., Miguet J.P., Vuitton D.A., Becker M., Landecy G., Mantion G. and Gillet M. : Recurrence of non-viral infectious diseases after liver transplantation. In : Immunological, metabolic and infectious aspects of liver transplantation. Eds Vuitton D, Balabaud C, Houssin D, Dhumeaux D; John Libbey Eurotext, Paris, 1991, 91-96

Bresson-Hadni S., Liance M., Meyer J.P., Houin R., Bresson J.L. and Vutton D.A. : Cellular immunity in experimental Echinococcus multilocularis infection. 2) Sequential and comparative phenotypic study of the periparasitic mononuclear cells in resistant and sensitive mice. Clinical and Experimental Immunology, 1990, 82, 378-383

Bresson-Hadni S., Miguet J.P., Vuitton D., Meyer J.P., Becker M.C., Didier D., Coche G., Weill F., Carbillet J.P., Landecy G., Mantion G. and Millet M. : L'echinococcose alveolaire hépatique humaine. Revue générale à propos de 80 cas. Semaine des Hôpitaux de Paris, 1988, 64, 2691-2701

Bresson-Hadni S., Vuttton D.A., Lenys D., Liance M. and Miguet J.P. : Cellular immune response in Echinococcus multilocularis infection in Humans : 1) Lymphocyte reactivity to Echinococcus antigens in patients with alveolar echinococcosis. Clinical and Experimental Immunology, 1989, 78, 61-66.

Capron A., Yarzabal L., Vernes A and Fruit J. : Le diagnostic immunologique de l'échinococcose humaine. Bilan personnel à propos de 400 observations. Pathological Biology, 1970, 18, 357-365.

Chikunguwo S.M., Kanazawa T., Dayal Y. and Stadecker M.J. : The cell-mediated response to schistosomal antigens at the clonal level. In vivo functions of cloned murine egg antigen-specific CD $4+\mathrm{T}$ helper type I Iymphocytes. Journal of Immunology, 1991, 147, 39213925.

GotTstein B., ECKert J. and Fey H. : Serological differentiation between Echinococcus granulosus and Echinococcus multilocularis infections in man. Zeitschrift für Parazitenkunde (Parasitology Research), 1983, 69, 347356.

Gottstein B., Mesarina B., Tanner I., Ammann R.W., Wilson J.F., ECKer J. and LANier A. : Specific cellular and humoral immune response in patients with different long-term courses of alveolar echinococcosis (infection with Echinococcus multilocularis). American Journal of Tropical Medicine and Hygiene, 1991, 45, 734-742.

Kagan I.G., Norman L. and Allain D.S. : Studies in echinococcosis : serology of crude and fractionated antigens prepared from Echinococcus granulosus and Echinococcus multilocularis. American Journal of Tropical Medicine and Hygiene, 1960, 9, 248-261
Judson D.G., Dixon J.B. and Skerritt G.C. : Occurrence and biochemical characteristics of cestode lymphocyte mitogens. Parasitology, 1987, 94, 151-160.

Liance M., Bresson-Hadni S., Vuttton D.A., Bretagne S. and Houin R. : Comparison of the viability and developmental characteristics of Echinococcus multilocularis isolates from human patients in France. International Journal of Parasitology, 1990, 20, 83-86

Miguet J.P. and Bresson-Hadni S. : Alveolar echinococcosis of the liver. Journal of Hepatology, 1989, 8, 373-379.

Miguet J.P., Bresson-Hadni S. and Vuitton D. Echinococcosis of the liver. In : Oxford textbook of clinical hepatology. Ed. Mc Intyre B., Benhamou J.P., Bircher J., Rizetto M., Rodes J. Oxford University Press, Oxford, 1991, 721730 .

Siracusano A., Teggi A., Quintieri F., Notarglacomo S., De Rosa F. and Vicari G. : Cellular immune response of hydatid patients to Echinococcus granulosus antigens. Clinical and Experimental Immunology, 1988, 72, 400405.

Vogel H. : Uber den Entwicklungszyklus and die Artzugehörigkeit des europäischen Alveolarechinococcus. Deutsche Medizinische Wochenschrift, 1955, 80, 931 932.

Vuttton D.A., Bresson-Hadni S., Laroche L., Kaiserlian D., Guerret-Stocker S., Bresson J.L. and Gillet M. : Cellular immune response in Echinococcus multilocularis infections in humans. 2) Natural killer cell activity and cell subpopulations in the blood and in the periparasitic granuloma of patients with alveolar echinococcosis. Clinical and Experimental Immunology, 1989, 78, 67-74.

Vuttton D.A., Bresson-Hadni S., Lenys D., Flalsse F., Liance M., Wattré P., Miguet J.P. and Capron A. : IgE dependent humoral immune response in Echinococcus multilocularis infection; circulating and basophil-bound specific IgE against Echinococcus antigens in patients with alveolar echinococcosis. Clinical and Experimental Immunology, 1988, 17, 247-252.

Accepté le 18 juillet 1994 